\section{UNIVERSITY \\ OF DEBRECEN}

FACULTY OF

HEALTH

NYÍREGYHÁZA

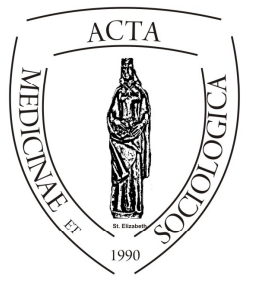

ACTA

MedSoc

VOLUME 5.

2014

\title{
Társas kapcsolatok Nyíregyházán
}

\author{
Huszti Éva \\ Debreceni Egyetem, Egészségügyi Kar, \\ Szociális és Társadalomtudományi Intézet
}

\begin{abstract}
In this study kin and some of non-kin ties are examined, focusing on strong ties like connections with members of family, relatives, friends and neighbours. The paper gives a picture about the dynamic of social contact during 2008-2012 among adult population in Nyíregyháza. Social activity is measured by number of friends; working of social support system of egos; memberships in clubs, organizations, etc.; frequency of meeting and talking and frequency of private gathering.
\end{abstract}

Keywords: social network, social connections, strong ties, solidarity, friendship, social support system.

DOI:10.19055/ams.2014.5/12-13/9

\section{A társas kapcsolatok jelentősége}

A társas kapcsolatok, vagy ha úgy tetszik, a társadalmi vagy kapcsolati tőke olyan eröforrás, melynek egyre nagyobb szerepe van mindennapjainkban. Az, hogy társak, „többiek” vesznek minket körül, biztosítja, biztosíthatja számunkra azt, hogy ne maradjunk ki a társadalom vérkeringéséből, hogy láthatóak maradjunk és lássunk másokat. A társas kapcsolatok nagymértékben hozzájárulnak a különböző típusú tőkefajták áramlásához. 


\section{Életminőség és társas kapcsolatok}

Andorka (1997) meghatározása szerint az életminőség az élet nem anyagi dimenzióiban megvalósított jóllét. Mások is hangsúlyozták, hogy pusztán az anyagi jólét (welfare) nem elegendő a minőségi élethez, a jólléthez (well-being). A minőségi élethez az anyagi javakon kívül szükség van nem anyagi javakra is (Allardt 1975; Simmel, 1973; Veblen, 1975; Bourdieu 1978, Riesman 1983; Beck 2003). Az életminőséggel foglalkozók általában megkülönböztetik az életminőség objektív (társadalmi környezeti) és szubjektív (individuálisan megélt) oldalát (Utasi, 2006). Bárhonnan is vizsgáljuk, a társas kapcsolatoknak az életminőséget alakító szerepe több kutatás megállapítása alapján is lényeges (p1. Johnsen 1998;). Ezek a kutatások többnyire a társadalmi kohéziót, integrációt, szolidaritást vizsgálták (Utasi, 2006).

A társas kapcsolatok vizsgálata évek óta fontos szerepet kap a Nyíregyháza felnőtt lakosságának életminőségét kutató panel felmérés témái között is. Mi sem bizonyítja ezt jobban, mint a 2010-es adatok kapcsán született FTI index, amelynek fontos komponense az egyént körülvevő kapcsolati háló (TakácsFábián, 2012).

„A kapcsolathálózatok biztonságot nyújtanak, lehetövé tesznek bizonyos anyagi forrásokhoz való hozzájutást, szerepet játszanak az egészség, a jólét megőrzésében. A társas kapcsolatok a társas támogatás (social support) révén jelentösen hozzájárulnak az egyén jó életminőségéhez. A társadalmi támasz/támogatás az egyik legfontosabb meghatározója annak, hogy az emberek biztonságban érzik-e magukat, kiegyensúlyozottnak, optimistának, elégedettnek, boldognak vallják-e magukat" (Utasi, 2006:299).

A társas kapcsolatoknak alapvetően két típusát különböztetjük meg: beszélhetünk erős illetve gyenge kötésekről, kapcsolatokról. Az erős kötésekhez szoktuk sorolni a szük családi kapcsolatokat, elsősorban a szülőket, gyermekeket, házas/élettársakat, a bizalmas barátokat, tehát olyanokat, akikkel az egyén rendszeres és intenzív kapcsolatban áll. A gyenge kapcsolatok, kötések olyan laza szálak, ismeretségek, melyek hidat képezve kapcsolják össze az egyéneket a tőlük távolabb állókkal, akiket az erős kapcsolatok révén nem tudnának elérni. Ezek a kapcsolatok nagyon fontosak a társadalmi integráció szempontjából. A szomszédok, ismerősök a gyenge kapcsolati típusba sorolhatók. Az erős kapcsolatok szerepe a mikro társadalmi integrációban elengedhetetlen, a gyenge kapcsolatok pedig, elsősorban úgynevezett „híd” szerepükkel, a makro társadalmi integrációt hivatottak biztosítani. Ugyancsak általánosságban, megállapítható, hogy azok, akik sok erős kötéssel, de kevés gyenge kapcsolattal bírnak, azoknál nagyobb a bezáródás veszélye, annak ellenére, hogy a kapcsolati hálójuk maga, a számos 
erős kötéssel, nagyon sürü. Ezeken a kapcsolatokon keresztül azonban nem tud széleskörü erőforrás áramlani. Így, azok, akiknek kapcsolati hálójában több gyenge kapcsolat van, könnyebben jutnak különböző erőforrástípusokhoz, könynyebben integrálódnak a társadalomba, sok esetben elönyösebb helyzetbe is juthatnak ezek által (Granovetter, 1973, 1974; Angelusz-Tardos, 1998; Gyarmati, 2009; Huszti 2012).

Jelen tanulmányban elsősorban a közeli, szoros kapcsolatok, a szük családhoz tartozók, valamint a baráti, rokoni kapcsolatok, illetve a nem rokoni kapcsolatok közül a szomszédok, mint a társas támogatás egyik fontos formája, illetve az egyéb ismerősök kerülnek részletesebb bemutatásra, elemzésre. A tanulmány foglalkozik a nyíregyháziak barátkozási szokásaival, a barátokhoz füződő kapcsolatok minőségével. Bővebben van módunk elemezni a mikro társadalmi szolidaritás azok formáit, melyek a családi, rokoni kapcsolatokon illetve a baráti, ismerősi szálakon keresztül megvalósuló társas támogatás egyes formáiban nyilvánulnak meg. Továbbá tárgyalásra kerülnek a városban élők magántársasági szokásai, illetve a közéletben való megjelenésük, aktivitásuk is.

\section{Módszer}

A Nyíregyháza Életminőségét vizsgáló panelkutatásban már harmadik alkalommal nyílt mód, hogy a városban élő felnőtt népesség kapcsolati hálóját, társas kapcsolatait is vizsgáljuk. A témához kapcsolódó vizsgált dimenziók 2012-ben is a következők voltak: baráti kapcsolatok mennyiségi és minőségi vizsgálata; társas támogatottság rokoni illetve nem rokoni körben; rokonokkal, barátokkal, szomszédokkal való kapcsolattartás gyakorisága; részvétel a közéletben; magántársasági összejövetelek gyakorlata.

A kérdőívben a „Hány barátja van Önnek?”, klasszikus kérdésen kívül alkalmaztuk a három barát vizsgálatot is, melyben azt vizsgáltuk, hogy bizonyos paraméterek szerint mennyire homogén vagy heterogén az egyént körülvevö baráti társaság. A szolidaritási hálót négy dimenzióban mértük: segítségnyújtás hivatalos ügyek intézésében, iskoláztatással kapcsolatban illetve munkahelykeresésben, valamint betegség esetén jó orvos találásában. Ezekben a kérdésekben a családtagok, rokonok illetve a barátok, ismerősök által nyújtott támogatási formákra, azok intenzitására voltunk kíváncsiak. Több kérdéssel vizsgáltuk a közeli, távoli rokonokkal, szomszédokkal, barátokkal való kapcsolattartás gyakoriságát, valamint a megkérdezettek magántársasági összejöveteli szokásait is: milyen gyakran járnak vendégségbe, fogadnak vendégeket, járnak el szórakozni. A nyíregyházi felnőttek beágyazottságát a helyi társadalomba a különböző klubokhoz, szervezetekhez való hovatartozással mértük. 


\section{Barátságok}

A modern fogyasztói társadalom még az alapvető emberi kapcsolatokat is rombolhatja, rossz irányba alakíthatja: kevesebb szerepet kap az érzelem, az önzetlenség. Ha beszükülnek az erös kapcsolatok is, akkor mi marad? Ilyen esetben romlik az egyén biztonságérzete, illetve a szubjektív életminőség is. Magyarországon a családi kötelékeknek van nagyon erős integráló szerepe, a családon kívüli kapcsolatok kevesek számára nyújtanak integrációs csatornát. (Utasi, 2006). Utasi korábbi kutatásai azt is alátámasztják, hogy akik magukat nagyon boldognak vagy boldognak érzik, azok között gyakoribb a bizalmas barát léte is az egyéni kapcsolathálóban (Utasi, 2002).

Mint azt már többen is leszögezték, a barátság fogalmát igen nehéz meghatározni, hiszen egészen mást jelent egyénenként, nemenként, korosztályonként, mást és mást jelent a különböző kultúrákban (pl. Albert F.-Dávid B., 2007). Azt azonban bátran kijelenthetjük, hogy maga a barátság nagyon fontos tényező az emberek életében és a barátok léte, nem léte nagyban hozzájárul személyiségünk fejlődéséhez és ahhoz, hogy hogyan éljük meg mindennapjainkat.

\section{Hány barátja van Önnek?"}

2012-ben a nyíregyházi felnőtt népesség átlagosan 4,8 baráttal bír, ami egyel kevesebb, mint az előző két hullámban mért átlagos szám. (2008-ban 5,52; 2010-ben 5,96). Ha a hazai, országos trendet vizsgáljuk, elmondhatjuk, hogy 2011-ben a megkérdezettek 5,5 baráttal rendelkeztek, ami növekedést jelent a 2004-ben mért 4,2-es átlaghoz képest. (TÁRKI Omnibusz, 2004 és 2011.) Nyíregyházán, legutóbbi, 2012-es mérésünkkor a férfiak számoltak be átlagosan több barátról (férfiak: 5 barát; nők: 4,6 barát).

2012-ben a nyíregyházi felnőtt lakosság 16\%-a nem rendelkezik egyetlen baráttal sem, de ebben a kategóriában csökkenést figyelhetünk meg az előző évekhez képest. Az országos adatok szerint a népesség 21\%-ának nincs egy barátja sem, ami teljesen megfelel az általunk 2010-ben mért arányoknak. (TÁRKI Omnibusz, 2011). 
"Hány barátja van Önnek?"

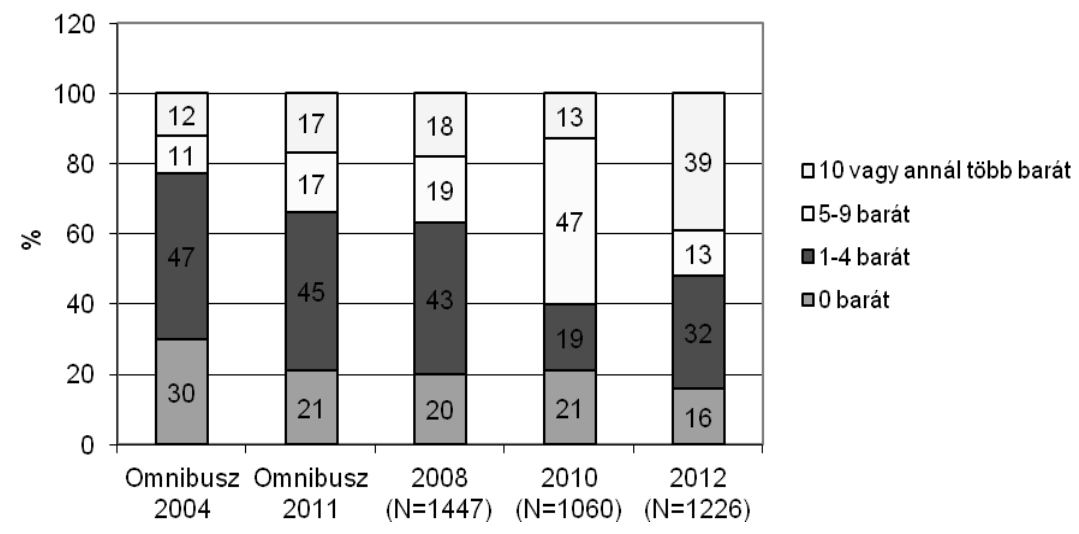

1.sz. ábra

Saját szerk.

Városi viszonylatban, az egy-négy baráttal rendelkezők arányában növekedés látszik, de nem éri el az országos szintet, a megkérdezettek 32\%-a tartozik ide. $\mathrm{Az}$ országos mérések szerint a felnőtt népesség majdnem felének (45\%) van maximum négy barátja. A következő két kategóriában a nyíregyházi adatok eröteljes átrendeződést mutatnak: míg 2010-ben az öt-kilenc baráttal rendelkezők aránya volt a legmagasabb (47\%) és a tíz vagy annál több baráttal bíróké a legalacsonyabb, addig 2012-ben éppen fordítva alakult a helyzet, azaz a több baráttal rendelkezők kategóriája lett népesebb (39 ill. 13\%). Az országos adatok egyenlö, 17-17\%-os arányt mutatnak a szóban forgó kategóriákban, azaz Nyíregyházán lényegesen magasabb azok aránya, akik tíz vagy ennél több barátról számoltak be.

A barátokkal nem rendelkezők között több a nő (60\%), az idős (60 éves és idősebb; 52\%), illetve az alacsonyabb iskolai végzettséggel (nincs érettségije) rendelkezők aránya (52\%). Ki kell emelni a házasok magas arányát $(65 \%)$ a baráttal nem rendelkezők között.

\section{A barátok száma korcsoportonként}

A városban mindhárom vizsgált évben érvényben maradt a negatív irányú összefüggés a kor és a barátok átlagos száma között, azaz minél idősebb valaki, annál kevesebb baráttal rendelkezik. Ez a tendencia egyébként hazai viszonylatban is így jelentkezik, az idősebb korcsoportok a társadalom izolált csoportjaihoz so- 
rolhatók. Azt is meg kell azonban említeni, hogy az idősebbek karcsúbb kapcsolati hálója nem törvényszerü: vannak olyan társadalmak, ahol minél idősebb valaki, annál nagyobb kapcsolathálóval bír. (Pl. Svájc, Kanada, Új-Zéland). Az ISSP (International Social Survey Programme) 2006-os adatai szerint például hazánkban a 60 év felettieknek csupán 11\%-a rendelkezik több mint húsz kapcsolattal, addig Svájcban az idősek 24\%-ának, Kanadában 35\%-ának, ÚjZélandon 37\%-ának van több mint húsz kapcsolata. ${ }^{1}$



2. sz. ábra. A barátok átlagos száma a különböző korcsoportokban 2008-2012.

Saját szerk.

A fiatalok továbbra is megőrizték vezető pozíciójukat a barátok átlagos száma tekintetében annak ellenére, hogy körükben is csökkent és csökken a megjelölt barátok száma. A 35-59 évesek átlagosan 5 barátot jelöltek meg 2012-ben, ami határozott visszaesés mind 2010-et, mind, pedig 2008-at figyelembe véve. Az idősebb korosztály esetében a barátok átlagos száma trendszerủen 3 és fél körül mozog, nincs lényegi változás.

\section{Barátok száma iskolai végzettség szerint}

Az iskolai végzettség és a barátok átlagos száma között egyenes irányú összefüggés mutatkozott mindhárom vizsgált évben: minél magasabb valakinek az iskolai végzettsége, annál több barátja van.

\footnotetext{
${ }^{1}$ Az ISSP kutatásban a jelzett évben 35 országban kérdezték többek között azt a kérdést, hogy „Hány emberrel van kapcsolata?”
} 


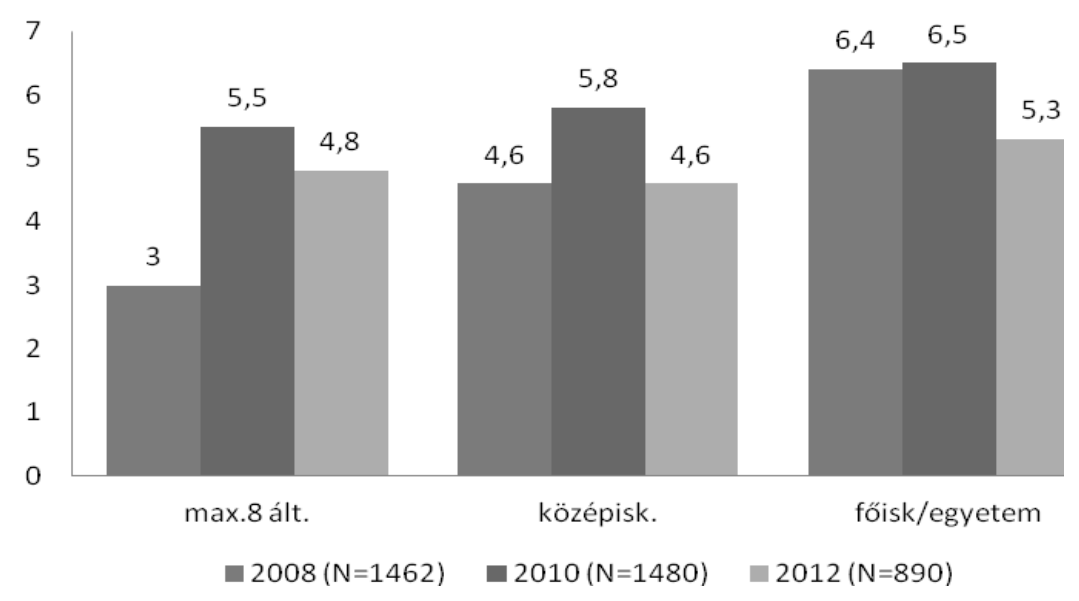

3.sz. ábra. A barátok átlagos száma iskolai végzettség szerint.

Saját szerk.

Az is jól látható az ábrán, hogy 2010-ben minden kategóriában növekedést mértünk 2008-hoz képest, legfrissebb, 2012-es adataink pedig visszaesést mutatnak az előző mérés adataihoz képest. A barátvesztés a magasabb iskolai végzettségüek körében a legjelentősebb (középiskolai végzettségüek esetén 5,8-ról 4,6-ra, föiskolai/egyetemi végzettség esetén, pedig 6,5-röl 5,3-ra). Fontos kiemelni, hogy a három csoportban mért átlagos barátszám között már nincs olyan jelentős különbség, mint az korábban, főként 2008-ban volt, egyfajta kiegyenlítődés látszik: az alacsonyabb iskolai végzettségúek körében nőtt a barátok átlagos száma, a felsőfokú iskolai végzettségüek között azonban csökkent. A felsőfokú iskolai végzettséggel rendelkezők tágabb baráti kapcsolatrendszere nem törvényszerü: egy másik, jelenleg is zajló összehasonlító kutatás eredményei szerint például Taiwanon az alacsony iskolai végzettségüeknek van több kapcsolatuk egy hét leforgása alatt ${ }^{2}$.

Barátok száma és gazdasági aktivitás

A gazdasági aktivitást vizsgálva azt mondhatjuk, hogy 2012-ben, akárcsak 2008ban, azok, akik a kérdezés időpontjában dolgoztak, átlagosan egyel több barátról számoltak be, mint azok, akik gazdaságilag nem voltak aktívak, nem dolgoztak a megkérdezés idején. Mindkét évben átlagosan 5 baráttal rendelkeztek a munkaerőpiacon jelenlévők, míg néggyel az onnan valamilyen okból (munkanélküli-

\footnotetext{
${ }^{2}$ Taiwan: max.általános iskolai végzettség - 56 kapcsolat/hét; magasabb iskolai végzettség - 44 kapcsolat/hét; Magyarország: max.általános iskolai végzettség - 14 kapcsolat/hét; magasabb iskolai végzettség - 23 kapcsolat/hét (David-Huszti-Barna-Fu, 2014)
} 
ség, gyes, gyed, nyugdíj, stb.) távolmaradók. 2010 ebből a szempontból eltér, hiszen akkor a gazdaságilag inaktív csoportoknál mértünk átlagosan több barátot. Úgy tünik azonban, hogy e tekintetben a 2012-es adatok a 2008-ban mért eredményekkel vannak összhangban és az inaktív csoportok az átlagosnál kevesebb barátról számoltak be.

\section{Elszigeteltek és „baráthalmozók”}

Ha abból indulunk ki, hogy a barátok nélkülözése a társadalmi izoláltság egyik elfogadott mérőeszköze (lásd még Albert-Dávid, 2012³), akkor azt mondhatjuk, hogy bizonyos társadalmi csoportokhoz való tartozás növeli az izoláció, elszigetelödés esélyét. Az Omnibusz 2011 vizsgálat szerint az özvegyek, a 60 évnél idősebb népesség és az alacsony iskolai végzettségüek társadalomi izolációja a legszembetünőbb.

Az országos adatokhoz hasonlóan Nyíregyházán is a nyugdíjasok, az alacsony iskolai végzettséggel rendelkezők, az özvegyek, az idősek azok, akiknek teljesen hiányoznak a baráti kapcsolataik. Az elszigetelődés esélyét jelentősen növeli, ha valaki szegény, egyedül él, elvált. Nemek tekintetében a nőknél erösebb az izoláció veszélye. (4. ábra)

A gyengék, tehetetlenek, forráshiányosak kimaradnak a közösségi szolidaritáshálóból, elesnek az esetleges lehetőségektől. Utasiék korábbi adatok (ISSP, 2001) alapján megállapították, hogy akiknek az erős kapcsolataik is hiányosak, vagy egyáltalán nem is léteznek, alig találnak kapcsolatokat más közösségben, azaz gyenge kapcsolataikat sem tudják úgy építeni, mint azok, akik rendelkeznek erős kapcsolatokkal. A társadalmi integráció ilyen mértékü reménytelensége esetén a társadalom érintett tagjai „,a mertoni anomikus stratégiák közül a „,viszszahúzódással" válaszolnak" (Utasi, 2006:41).

\footnotetext{
${ }^{3}$ http://www.tarki.hu/hu/news/2012/kitekint/20120215.html
} 


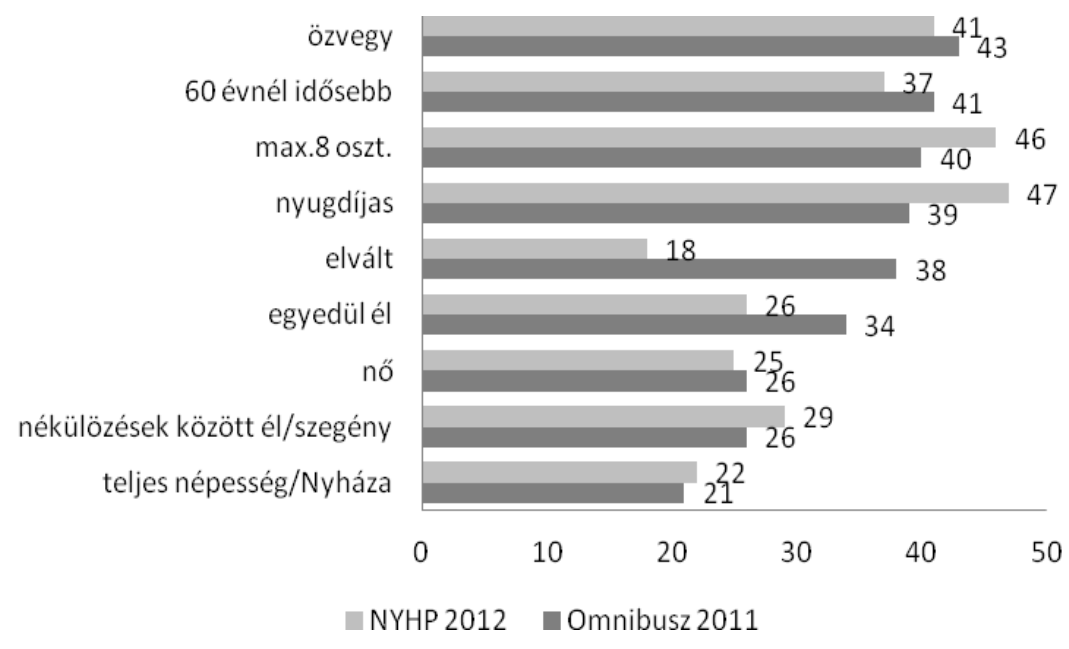

4. sz. ábra. Az elszigeteltek (baráttal egyáltalán nem rendelkezők) aránya egyes társadalmi csoportokon belül (\%).

Saját szerk.

Az érem másik oldala, mikor valakinek nagyon sok barátja van, „baráthalmozó”, azaz 10 vagy több baráttal rendelkezik. Ide mind országosan, mind városi viszonylatban a nőtlenek/hajadonok, a tanulók és a gondok nélkül, jómódban élők tartoznak.

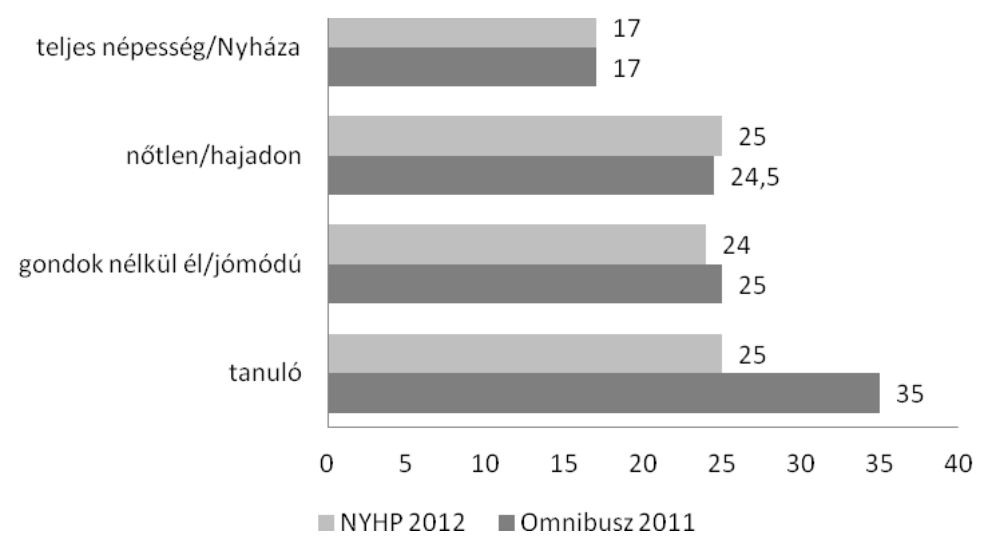

5. sz. ábra. A baráthalmozók aránya egyes társadalmi csoportokban (\%).

Saját szerk. 


\section{Társas támogatás 2008-2012}

A társadalom mikroszintjén (kisközösségek) a bizalom alapú szolidaritás jelenti a társadalmi egység megteremtésének forrását (Utasi, 2002). Ezt az integrációt biztosíthatják egyrészt a családi, rokoni kapcsolatok, másrészt pedig a családok kívüli kapcsolatok, vagy mindkettö. Elmondható, hogy akinek intenzív családi, rokoni és családon kívüli kapcsolatrendszere van, az az egyén nagyon erősen beágyazódott az adott társadalomba, aktív részese annak. Vannak olyan egyének, akiknek a családi kapcsolatai erősebbek, illetve olyan is, akik inkább a családon kívüli társakkal ápolnak szorosabb, gyakoribb, intimebb kapcsolatot. Azok az emberek, akiknek mind a családi, mind a családon kívüli kapcsolatrendszere alacsony intenzitású, csak gyengén integrálódik az őt körülvevő társadalomba (Utasi, 2002).

A következőkben néhány névgenerátor típusú kérdés mentén azt vizsgáltuk évről évre, hogy vannak-e a nyíregyháziaknak olyan kapcsolataik, akikre bizonyos esetekben számíthatnak. Négy szituációt vizsgáltunk: 1) hivatalos ügyeknél segítség; 2) iskoláztatással, iskolába való bejutásnál segítség; 3) munkahely, álláskeresésnél segítség; 4) orvos keresésnél segítség.

\begin{tabular}{|c|c|c|c|c|c|c|}
\hline $\begin{array}{c}\text { Van-e Önnek olyan család- } \\
\text { tagja, rokona/ barátja, is- } \\
\text { meróse, aki... }\end{array}$ & \multicolumn{3}{|c|}{$\begin{array}{c}\text { Családtagja, rokona } \\
\text { van (\%) }\end{array}$} & \multicolumn{3}{c|}{ Barátja, ismeröse van } \\
\cline { 2 - 7 } & $\mathbf{2 0 0 8}$ & $\mathbf{2 0 1 0}$ & $\mathbf{2 0 1 2}$ & $\mathbf{2 0 0 8}$ & $\mathbf{2 0 1 0}$ & $\mathbf{2 0 1 2}$ \\
\hline $\begin{array}{c}\text { segítséget nyújt, vagy nyújtott } \\
\text { Önnek hivatalos ügyintézés- } \\
\text { hez (pl. önkormányzati enge- } \\
\text { délyek, kölcsönök, hitelek, } \\
\text { szerződéskötések, stb.)? }\end{array}$ & 50 & 50 & 55 & 30 & 40 & 42 \\
\hline $\begin{array}{c}\text { segítséget nyújjtott iskolázta- } \\
\text { tással, továbbtanulással kap- } \\
\text { csolatban (pl. bejuttatta egye- } \\
\text { temre vagy jó szakmát nyújtó } \\
\text { iskolába)? }\end{array}$ & 18 & 20 & 22 & 19 & 16 & 19 \\
\hline $\begin{array}{c}\text { segítséget nyújt/nyújtott egy } \\
\text { jó állás, munkahely megszer- } \\
\text { zéséhez? }\end{array}$ & n.a. & 25 & 29 & n.a. & 30 & 30 \\
\hline $\begin{array}{c}\text { betegség esetén segít/segített } \\
\text { jó orvost szerezni? }\end{array}$ & 47 & 55 & 60 & 33 & 45 & 42,5 \\
\hline
\end{tabular}

1.sz. táblázat Társas támogatás 2008-2012. 
Az előző mérésekhez hasonlóan, 2012-re tovább nőtt azok aránya, akiknek van olyan közeli vagy távolabbi hozzátartozója, ismerőse, akik segítségére számíthat hivatalos ügyek intézése esetén. Rokoni kapcsolatok esetén azonban még így is jóval alacsonyabbak a városi adatok, mint az országos támogatási arány $(75 \%$ HÉV, 2008). A nem rokoni kapcsolatokat vizsgálva viszont városi szinten a folyamatos növekedés mutatható ki, ami már 2008-ban is felülmúlta az országos arányokat (15\% - HÉV, 2008). A hivatali ügyek intézéséhez tehát Nyíregyházán az emberek jobban tudják alkalmazni a nem rokoni kapcsolataikat, ami egyúttal utal arra is, hogy a nyíregyháziak rendelkeznek olyan, családon kívüli kapcsolati tőkével, akik segítséget tudnak nyújtani hivatalos ügyeik intézése során. Ezt az állítást erősíti a panelkutatás további részeit feldolgozó tanulmány is, mely szerint a nyíregyháziak családtagjaik után a barátok illetve az ismerősök által alkotott természetes támogató rendszert egyre növekvő arányban veszik igénybe és utánuk jóval leszakadva következik csak a mesterséges támaszt nyújtó hivatal. Fontos kiemelni továbbá, hogy például az igénybe vehető segélyekről is elsősorban ismerőseiktől szereznek tudomást a megkérdezettek (Balogh-Fábián, 2012).

Az iskoláztatás terén nyújtott rokoni kapcsolati tőke esetén is növekedésröl beszélhetünk, illetve növekedést mutat azok aránya is, akik egy jó állás megszerzéséhez családtagjaikat, rokonaikat tudják mozgósítani. Ezen támogatási típusok esetén is a városi adatok magasabb támogatottságot mutatnak, mint az országos adatok (pl. jó állás megszerzéséhez az országos adatok 10\%-os rokoni és $12 \%$-os nem rokoni támogatást jeleznek - HÉV, 2008). Ki kell emelni azonban, hogy a távolabbi, gyengébb kapcsolatok (pl. ismerős) aránya a városi adatok szerint stagnál, azaz éppen azok a gyenge kapcsolatok terén, amelyek erősségét, fontosságát a network-irodalom (lásd pl. Granovetter) hangsúlyozza, nem látunk növekedést, bár visszaesésröl sincs szó.

Az erős kapcsolatok igénybevételének lehetősége ugyancsak növekedést mutat, ha egy jó orvos megszerzéséről van szó. Ebben az esetben azonban némi csökkenést tapasztalunk, ha barát vagy ismerös segítségét kell kérnünk, de még így is jóval az országos arányok feletti értékeket láthatunk (39\%-os rokoni illetve $25 \%$-os nem rokoni támogatottság - HÉV, 2008).

Összességében megállapítható, hogy a városban a mikroszolidaritási háló tovább növekedett, azaz az emberek a vizsgált kérdésekben egyre növekvő mértékben számíthatnak közeli és távolabbi rokonaikra. A barátok és a gyengébb kapcsolatnak számító ismerősök segítsége a hivatalos ügyek intézése, illetve az iskoláztatással kapcsolatban mutatott emelkedést. 


\section{Társas támogatás a különböző társadalmi rétegekben 2008-2012}

Érdekes lehet annak összehasonlítása, hogy vajon van-e különbség a különbözö, erős illetve gyenge, rokoni, nem rokoni kapcsolatokon áramló erőforrások terén aszerint, hogy valaki milyen társadalmi helyzetben van. Angelusz és Tardos 2005-ös kutatásukban többek között azt is kimutatták, hogy az évek során hazánkban egyre erősödött az előnyök és hátrányok összekapcsolódása a különböző erőforrásokban, azaz aki egyfajta erőforrás terén szükölködik, az nagy valószínüséggel hiányt szenved másfajta erőforrások birtoklásában is. Pl. akinek hosszú ideig nincs munkahelye, annak megszakadnak a baráti, társasági kapcsolatai, leértékelődik partnerként, nem biztos, hogy huzamosabb ideig számíthat a családi támogatásra, stb. (Angelusz-Tardos, 2006)

Jelen esetben a szegény-nem szegény dichotóm kategóriát vesszük alapul, ahol szegénynek számított az, akinek a jövedelme a vizsgált évben a medián jövedelem $60 \%$-ánál kevesebb ${ }^{4}$.

A mikrotársadalmi szolidaritás vizsgált aspektusaiban (segítségnyújtás különböző helyzetekben) 2008-ban és 2010-ben egyértelmủen a nem szegény rétegekhez tartozók élveztek elönyt.

2012-ben jellemző, hogy a vizsgált helyzetekben a szegény kategóriába tartozók átlag alatti támogatásra számíthattak rokonaiktól. Ezzel szemben, átlag feletti támogatást éreznek a hivatalos ügyintézéssel, az iskoláztatással, továbbtanulással és a munkavállalással kapcsolatban a nem rokoni kapcsolatoktól, azaz a gyengébb kötésektől. Az, ha számíthatnak ilyen jellegü támogatásra a megkérdezettek bizonyos fokon, előnyös képet mutat mind a mikro (barátok), mind a makrotársadalmi szolidaritás (ismerősök) tekintetében. (2. sz. táblázat)

\footnotetext{
${ }^{4}$ A szegénységet mérő változó kialakításánál a háztartások az OECD2 skála szerint lettek súlyozva.
} 


\begin{tabular}{|c|c|c|c|c|c|c|}
\hline \multirow{2}{*}{$\begin{array}{|lr|}\text { Van-e Önnek olyan } \\
\text { családtagja, rokona, } \\
\text { aki segítséget nyújt, } \\
\text { vagy nyújtott Ön- } \\
\text { nek... } \\
\end{array}$} & \multicolumn{2}{|c|}{2008} & \multicolumn{2}{|c|}{2010} & \multicolumn{2}{|c|}{2012} \\
\hline & $\begin{array}{c}\text { szegény } \\
\%\end{array}$ & \begin{tabular}{|c|} 
nem \\
szegény \\
\%
\end{tabular} & $\begin{array}{c}\text { szegény } \\
\%\end{array}$ & $\begin{array}{c}\text { nem } \\
\text { szegény } \\
\%\end{array}$ & $\begin{array}{c}\text { szegény } \\
\%\end{array}$ & $\begin{array}{c}\text { nem } \\
\text { szegény } \\
\%\end{array}$ \\
\hline $\begin{array}{l}\text { hivatalos ügyintézés- } \\
\text { hez? }\end{array}$ & 34 & 47 & 49 & 50 & 53 & 57 \\
\hline $\begin{array}{l}\text { iskoláztatással, tovább- } \\
\text { tanulással kapcsolat- } \\
\text { ban? }\end{array}$ & 20 & 24 & 15,5 & 21 & 20 & 23 \\
\hline $\begin{array}{l}\text { egy jó állás, munka- } \\
\text { hely megszerzéséhez? }\end{array}$ & n.a. & n.a & 23 & 26 & 25 & 32 \\
\hline $\begin{array}{l}\text { betegség esetén jó } \\
\text { orvost szerezni? }\end{array}$ & 35,5 & 46 & 50 & 58 & 56,5 & 63 \\
\hline $\begin{array}{l}\text { Van-e Önnek olyan } \\
\text { barátja, ismerőse, aki } \\
\text { segítséget nyújt, vagy } \\
\text { nyújtott Önnek... }\end{array}$ & & & & & & \\
\hline $\begin{array}{l}\text { hivatalos ügyintézés- } \\
\text { hez? }\end{array}$ & 31 & 35 & 31 & 44 & 47 & 44 \\
\hline $\begin{array}{l}\text { iskoláztatással, tovább- } \\
\text { tanulással kapcsolat- } \\
\text { ban? }\end{array}$ & 11,5 & 16 & 11 & 17 & 24 & 19 \\
\hline $\begin{array}{l}\text { egy jó állás, munka- } \\
\text { hely megszerzéséhez? }\end{array}$ & 15 & 22 & 20 & 33 & 39 & 30 \\
\hline $\begin{array}{l}\text { betegség esetén jó } \\
\text { orvost szerezni? }\end{array}$ & 20 & 37,5 & 37 & 48 & 39 & 45 \\
\hline
\end{tabular}

2. sz. táblázat.

\section{Kapcsolattartás rokonokkal, barátokkal, szom- szédokkal 2008-2012}

Az életbevágóan fontos problémáknál, krízishelyzeteknél a családi kötelék az, amely a legfontosabb és legbiztosabb támogatást tudja nyújtani. Ezek előnyei, hogy bizonyos normák által biztosítottak, könnyen mozgósíthatók, mobilizálhatók és irányíthatók.

A családi köteléken belül beszélhetünk közeli és távoli családtagokról, rokonokról. Azért fontos különbséget tenni közöttük, mert nem ugyanaz az elvárás a közeli, mint a távoli családtagok, rokonok esetében. A tágabb rokonság szerepe például 
elhanyagolható a rutinszerü vagy akár a hirtelen fellépő problémák megoldásánál; emocionálisan és instrumentálisan is kevéssé számítunk rájuk (Szabó, 2005).

A szük családi kapcsolatokon kívül, a társadalmi integráció, a szolidaritás tekintetében, fontos szerepe van a családon kívüli, nem rokoni kapcsolatoknak is. Több kutatás is megerősítette azt az állítást, hogy ha nincs intenzív családtag az ember közvetlen környezetében, akire számíthat, akkor a barát lesz az, akitől a társas támogatást megkaphatja. A baráti kapcsolatok alapvetően önkéntes alapú kapcsolatok, nem úgy, mint a rokonokkal vagy akár a szomszédokkal való kapcsolat, melyek kevésbé nevezhetők önkéntes alapon szerveződőnek. A szomszédok általában társaságot és kisebb szolgáltatásokat biztosítanak.

A kapcsolattartás gyakorisága fontos fokmérője lehet az adott kapcsolat erősségének; szívesebben találkozunk gyakrabban olyan emberekkel, akiket kedvelünk, jó véleményünk van róla és értékeljük egymás társaságát. Azonban azt is tudjuk, hogy sok esetben nem válogathatjuk meg a találkozás gyakoriságát olyanokkal, akikhez gyengébb kapcsolat füz. A szomszéddal, vagy a munkatárssal való kapcsolat megítélése például nagyon félreértelmezhető, ha a találkozási gyakoriságot vesszük alapul. Nem feltétlenül lesz erős az a kapcsolat tehát, amelyre a gyakori találkozás jellemzö (Marsden-Campbell, 1984).

Kutatásunkban a családi kapcsolatok közül mind a közeli családtagokkal (szülők, gyermek(ek), testvér(ek)), mind a távolabbi rokonokkal való kapcsolattartás gyakoriságát mértük. A nem rokoni kapcsolatok közül a barátokkal, illetve a szomszédokkal való kapcsolattartást vizsgáltuk.

A közeli családtagokkal való kapcsolattartás gyakoriságát egy olyan skálán mértük, mely a napi, rendszeres kapcsolattartástól a „soha” kategóriáig tart. Teljesen természetes módon, a megkérdezettek közeli családtagjaikkal, szüleikkel, gyermekükkel, testvéreikkel nagyon gyakori, leginkább napi szintü, de legalább heti szintü kapcsolatban vannak.

Ha a távolabbi rokonokkal való kapcsolattartást vizsgáljuk, azt lehet elmondani, hogy esetükben a havi rendszeres kapcsolattartás a leggyakoribb.

A nem rokoni kapcsolatok közül a barátokkal való kapcsolattartás gyakoriságára a heti rendszeresség jellemző, míg a szomszédokkal a heti többszöri és a napi szintü kapcsolattartás a leggyakoribb, mely alapvetően a fizikai közelséggel magyarázható. 


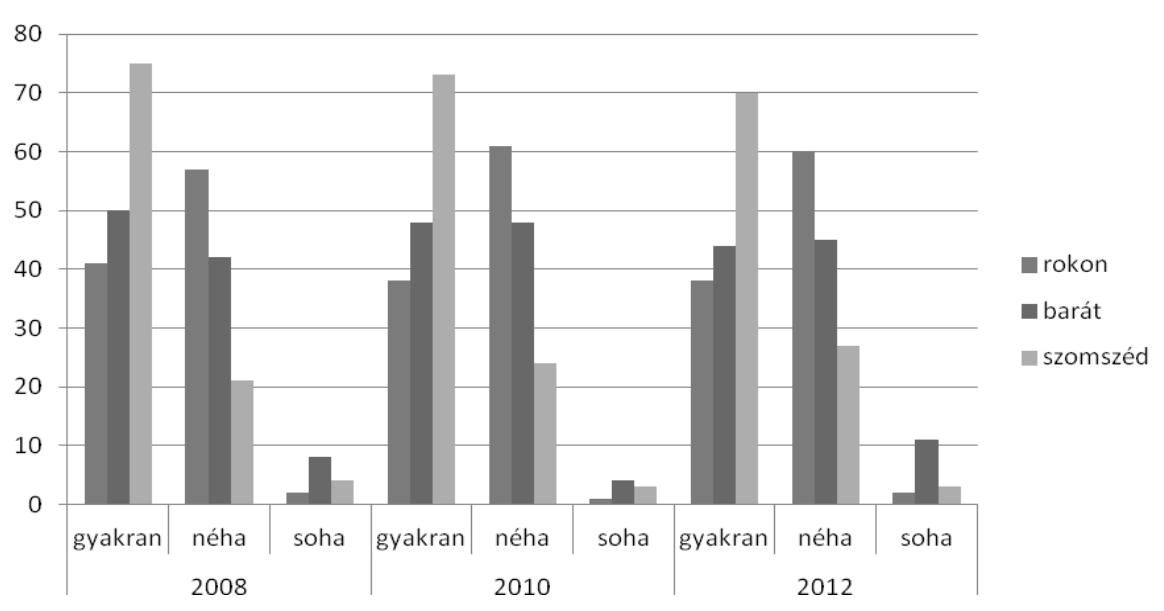

6. sz. ábra. A rokoni és nem rokoni kapcsolatokkal való találkozás/beszélgetés gyakorisága, 2008-2012.

Saját szerk.

A rokonokkal való kapcsolattartás, amit a találkozások gyakoriságával mértünk, az évek során ritkulni látszik: egyre csökken a gyakori és ezzel párhuzamosan növekszik a ritkább találkozás velük. Az általában erős kapcsolatnak számító barátokkal történő találkozás gyakorisága is ritkul: egyre csökken azok aránya, akik barátaikkal gyakran (naponta, hetente) találkoznak és növekszik a ritkább kapcsolattartás. Arra is kíváncsiak voltunk, hogy milyen gyakran beszélgetnek a megkérdezettek szomszédaikkal. Mindhárom vizsgált évben a szomszédokkal való beszélgetés volt a leggyakoribb, bár ennek mértéke is egyre csökkenő tendenciát mutat és növekszik a ritkuló beszélgetések gyakorisága.

A szomszédokkal való beszélgetés gyakoribbá válása és a barátokkal való találkozás ritkulása nem feltétlenül jár együtt a baráti és szomszédi kapcsolatok minőségi változásával is, tehát nem biztos, hogy a ritkuló baráti kapcsolatok gyengébbek és a gyakoribbá váló szomszédi kapcsolatok erősebbek lesznek. Egy másik mérésünkben, többek között, azt mutattuk ki, amit Marsden és Campbell is hangsúlyozott (lásd fentebb), azaz, hogy a találkozás gyakorisága nem biztos, hogy pozitívan befolyásolja az adott kapcsolat minőségét. A kapcsolat erősségét mérő, általunk több változóból szerkesztett, SoT (Strength of Ties) index szerint a közeli barátokkal lényegesen erősebb a kapcsolat, mint az egyébként gyakoribb találkozást mutató szomszédokkal (Huszti-Dávid-Vajda, 2013). 


\section{Magántársasági összejövetelek 2008-2012}

„A magántársaságok, illetve baráti körök olyan informális kapcsolatkörök, amelyek az élet számos korábbi helyszinén - különbözö közös együttmüködés során létrejött kapcsolatból (szomszédságból, munkahelyről, iskolából, véletlen ismertségböl, formális intézményi kapcsolatból stb.) - szervezödhetnek, az ott létrejött kötelékekböl szimpátia, érdek, közös cél vagy csupán a tradíció, megszokás révén kiválogatódnak és bizalmas szolidaritás-körré rendezödnek.” (Utasi, 2013:68)

És hogy miért fontosak ezek a magántársaságok? Hogy továbbra is Utasi Ágnes gondolatait idézzem, azért, mert „Ezek a kis közösségek a családon kívüli legközvetlenebb közösségi lét és közélet alapjai, fundamentumai”. (Utasi, 2013:68). Korábban említettük már, hogy a családon kívüli kapcsolatok, az úgynevezett gyenge kötések azok, melyek hidat képeznek a társadalom kisebb egységei, közösségei között és csatornázzák be ezeket a nagyobb társadalomba, biztosítják számukra a társadalmi integrációt.

A magántársasági összejöveteleknek 2012-ben is, akárcsak a korábbi években, három aspektusát vizsgáltuk: milyen gyakran mennek vendégségbe, látogatóba a megkérdezettek; milyen gyakran fogadnak vendégeket, látogatókat; milyen gyakran találkoznak barátaikkal, ismeröseikkel presszóban, sörözőben, étteremben vagy más nyilvános helyen.

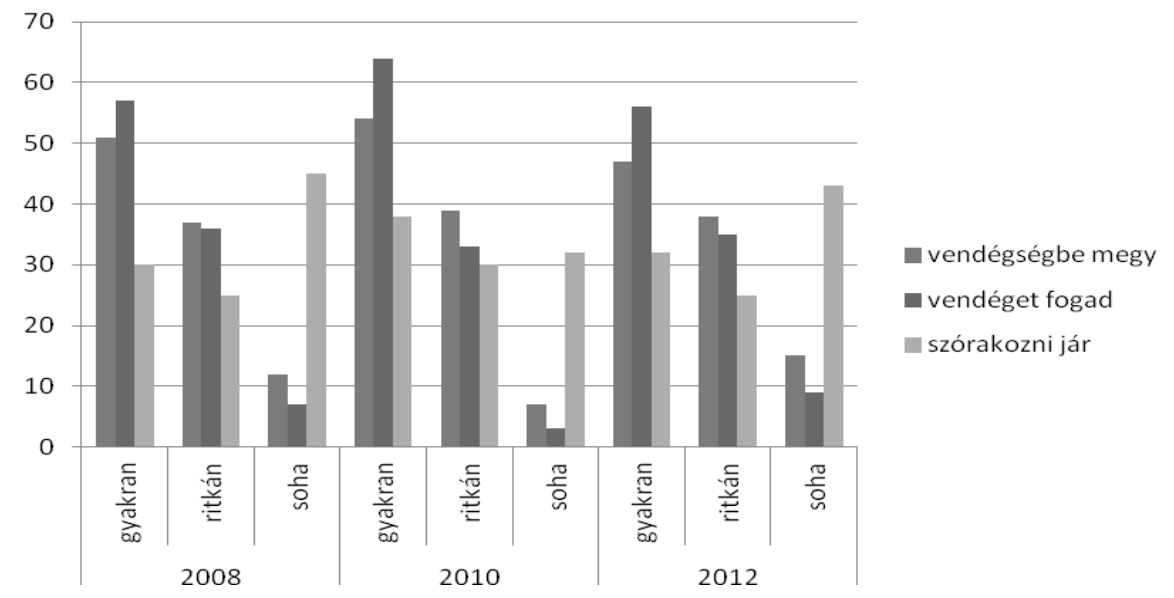

7. sz. ábra. Magántársasági összejövetelek 2008-2012.

Saját szerk. 
A nyíregyházi felnőttek körében, akárcsak az elmúlt vizsgálatok alkalmával, a vendégfogadás a leggyakoribb, a megkérdezettek több mint fele mindhárom adatfelvétel idején gyakori vendégfogadásról számoltak be, azaz szívesen fogadtak otthonukban vendégeket. Ettől kisebb arányban járnak gyakran vendégségbe a megkérdezettek és a legkevésbé a gyakori szórakozni járás jellemzi a kérdésre válaszolókat mindhárom vizsgálati évben.

A fenti adatsorok szerint a gyakran vendégségbe járók aránya a 2010-es növekedést követően 2012-re a négy évvel korábbi gyakoriság alá esett vissza (47\%), azaz csökkent azok aránya, akik heti vagy havi rendszerességgel járnak vendégségbe. Állandósulni látszik azok aránya (38\%), akik ritkán (évente néhány alkalommal), de azért mégis elmennek vendégeskedni olykor-olykor.

A megkérdezettek vendégfogadási kedve a 2010-es „,kiugrás” után (64\%) visszaesett a 2008-as szintre (57 ill. 56\%); a megkérdezettek felére jellemző, hogy gyakran, azaz heti vagy havi rendszerességgel fogad vendéget otthonában. Az évente néhány alkalommal történő vendégfogadás 35\% körül állandósul.

A szórakozni járás továbbra is tehát a legritkábban előforduló társasági esemény a nyíregyházi felnőttek körében. A gyakori szórakozás a megkérdezettek harmadára, míg az évente néhányszor történő szórakozás negyedükre jellemző.

2012-re minden vizsgált dimenzióban növekedett azok aránya, akik a ,soha” kategóriát választották: soha nem jár vendégségbe a megkérdezettek 15\%-a; soha nem fogad vendéget a megkérdezettek $9 \%$-a; illetve soha nem jár szórakozni a megkérdezettek 43\%-a. Ez a tendencia azonban nem mutat kedvező képet a fentebb említett szolidaritás-körök épüléséről. Azok között, akik nem járnak sehová és vendéget is ritkán vagy soha nem fogadnak, az alsó és a középrétegekből tartoznak nagyobb arányban, amely ezen rétegek izolálódási folyamatára veszélyére hívja fel a figyelmet.

\section{Közélet 2008-2012. Tagság szervezett közösségekben}

A szervezett közösségeket elsősorban az különbözteti meg a fentebb tárgyalt magántársaságoktól, hogy itt már rögzített szabályok, müködési elvek szabhatják meg a közös tevékenységet, együtt töltött idöt (Utasi, 2013).

2012-re némiképp tovább növekedett azok aránya (30\%) a városban, akik valamilyen, általunk felsorolt klubhoz, közösséghez tartoznak. Azonban még így is nagyon magas, 70\% azoknak a 18 éven felülieknek az aránya, akik nem járnak semmilyen közösségbe. A közösségi részvétel tehát még mindig nagyon ala- 
csony a városban. (2008-ban 25\%-os, 2010-ben 27\%-os részvételi arányt regisztráltunk.)

Meg kell azonban említeni, hogy ezekkel az arányokkal Nyíregyháza lényegében nem tér el a hazánkra jellemzö, és nemzetközi kutatásokkal is alátámasztott, trendtől, hiszen Magyarország lakosságának csupán negyede tagja valamilyen civil szervezetnek. 2009-es felmérés adatai szerint, azok közül, akik tagjai valamilyen szervezetnek, legtöbben valamilyen sportegyesületnek a tagjai (18\%), illetve a vallási közösségekhez való tartozás jellemző (16\%) (Utasi, 2013).

Nyíregyházán továbbra is $20 \%$ azok aránya, akik legalább egy közösséghez tartoznak és 7\%-on stagnál azok aránya, akik a felsoroltak közül két közösséget, csoportot is megjelöltek.

Ha a különböző típusú klubokat, csoportokat, közösségeket vizsgáljuk, elmondható, hogy a helyiek részvételi aránya leginkább a vallási közösségekhez való tartozásban növekedett a vizsgált évek során, ezen kívül nagyon kis arányban, de növekedést lehet látni a különböző szabadidős csoportokhoz, illetve a helyi szomszédsági csoportokhoz való tartozás terén is.

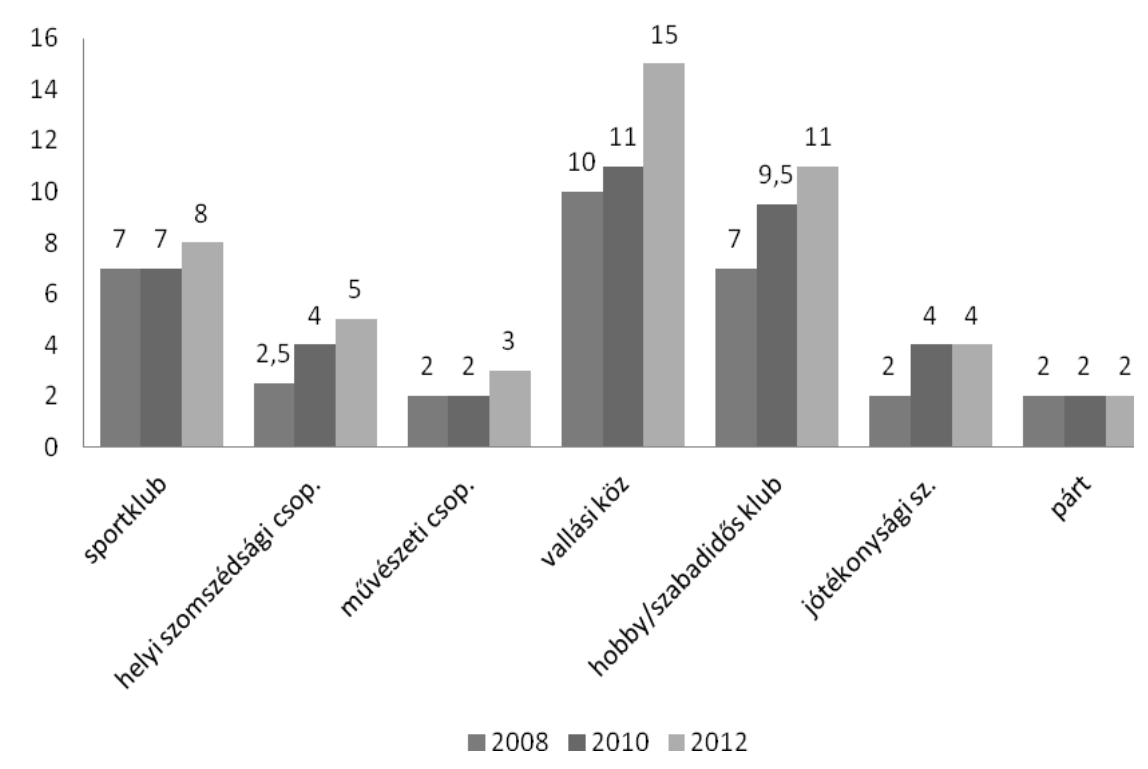

8. sz. táblázat. „Tagja-e Ön valamilyen klubnak vagy szervezetnek?” (\%). Saját szerk. 
2012-ben azok, akik képviseltetik magukat a közélet különböző színterein, elsősorban középkorúak és az idősebbek. Továbbra is jellemző, hogy minél jobb réteghelyzetben van valaki, annál valószínúbb, hogy megtalálható a közélet színterein. Az iskolai végzettség növekedésével egyenes arányban növekszik a valamilyen klubhoz, csoporthoz, közösséghez tartozók aránya. (Mindkét esetben $\mathrm{p}<0,005$.)

A közélet színterei, a közösségekhez, csoportokhoz való tartozás lehetőséget nyújtanak arra, hogy gyenge kapcsolatokat építsünk erőforrásaink erősítése érdekében, így azoknak, akik jelen vannak ezeken a fórumokon, nagyobb esélyei lehetnek érdekeik artikulálására is. Amint láttuk, a jobb társadalmi rétegek találhatók meg jobban a közélet színterein, tehát az egyébként is erősebb rétegek tudják tovább erősíteni helyzetüket.

\section{Összefoglalás}

2012-ben a nyíregyházi felnőtt korú népesség körében a barátok átlagos száma eggyel kevesebb, mint a megelőző, 2010-es mérés idején, viszont csökkent azok aránya, akik egyetlen baráttal sem rendelkeznek, ami pozitív elmozdulásnak mondható. Jelentősen nőtt azok aránya, akik népes baráti társaságot tudhatnak maguk körül, ami ugyancsak kedvező változás. Az elszigeteltek közé, akik egyetlen baráttal sem rendelkeznek a nyugdíjasok, az alacsony iskolai végzettségüek, az özvegyek és az idősek tartoznak. A baráthalmozók továbbra is a fiatalok, nőtlenek/hajadonok és a jómódúak.

A társas támogatást vizsgálva megállapítható, hogy tovább nőtt azok aránya, akik egyre növekvő mértékben számíthatnak közeli és távoli családtagjaik segítségére bizonyos ügyek intézése során. A nem rokoni kapcsolatok jelentősége a hivatalos ügyintézéseknél számottevő. A különböző társadalmi rétegekhez tartozók társas támogatását az jellemzi, hogy a társadalom alsó rétegeihez tartozók a családtagoktól várható támogatások esetén minden vizsgált kategóriában átlag alatti támogatással rendelkeznek, míg a barátok, ismerősök támogatása 2012-ben átlag feletti ebben a társadalmi kategóriában. Úgy tünik tehát, hogy a közeli, erōs kapcsolatok (családtagok) kezdenek kifogyni az adható támogatásokból, nem ök jelentik elsősorban a társas integráció útját. A barátok, ismerősök erősödő támogatási hajlandósága viszont a gyenge kapcsolatok jelentőségének növekedésére utal. Ez a folyamat utalhat a nyugati, polgárosult minták jelenlétére is. A következő mérés idején érdemes lehet szétszedni és külön vizsgálni az inkább közeli kapcsolatnak számító barátok, illetve a gyenge kötések közé sorolható ismerősök támogatási erejét.

A kapcsolattartás gyakoriságát tekintve összefoglalóan azt mondhatjuk, hogy a rokonokkal való találkozás tovább ritkul és ugyanez mondható el az ugyancsak 
erős kapcsolatnak számító barátokkal való kapcsolattartásról is. A szomszédokkal való beszélgetés továbbra is meglehetösen gyakori (a megkérdezettek 70\%-a gyakran beszélget szomszédaival), de ez az arány is évröl évre csökken.

A magántársasági összejövetelekről szólva a nyíregyházi felnőttek szívesen és gyakran fogadnak vendégeket, ennél kicsit ritkábban járnak vendégségbe és legkevésbé a szórakozni járás jellemzi őket. Meg kell jegyezni, hogy 2012-re minden kategóriában nőtt azok aránya, akik soha nem fogadnak vendégeket, nem járnak vendégségbe és szórakozni sem.

2012-re kis mértékben ugyan, de tovább növekedett azok aránya, akik azt mondták, hogy tagjai valamilyen szervezett közösségnek, de még így is nagyon magas azok aránya (70\%), akik viszont nem tartoznak semmilyen közösséghez. A növekedés elsősorban a vallási közösségekhez való tartozás gyakoriságában mutatható ki.

\section{Felhasznált irodalom}

1. Allardt, E. (1975): Dimensions of Welfare in a Comparative Scandinavian Study. Research Reports, 9. University of Helsinki.

2. Albert F., Dávid B. (2007): Embert barátjáról. A barátság szociológiája. Századvég, Budapest.

3. Andorka R. (1997): Bevezetés a szociológiába. Osiris, Budapest.

4. Angelusz R., Tardos R. (1998): A kapcsolathálózati erőforrások átrendeződésének tendenciái a kilencvenes években. In: Kolosi T. - Tóth I.Gy., Vukovich Gy. (szerk.): Társadalmi Riport, 1998.

5. Angelusz R. - Tardos R. (2006): Hálózatok a magyar társadalomban. In: Kovách Imre (szerk.) Társadalmi metszetek. Érdekek és hatalmi viszonyok, individualizáció és egyenlőtlenség a mai Magyarországon. Budapest, Napvilág Kiadó.

6. Balogh E., Fábián G. (2012): Támogató rendszerek, szociális problémák és segélyezés. In: Fábián G., Patyán L., Huszti É. (szerk): Életminőség Nyíregyházán 2008-2010. START Nonprofit Kft. Nyíregyháza. pp.135-154.

7. Beck, U. (2003): A kockázat-társadalom. Út egy másik modernitásba. Andorka Rudolf Társadalomtudományi Társaság, Századvég Kiadó, Budapest.

8. Bourdieu, P. (1978): A társadalmi egyenlőtlenségek újratermelődése. Gondolat Kiadó, Budapest.

9. Dávid, B., Huszti É., Barna I., Fu, Y-ch. (2014): Egocentric Contact Network in Comparison: Taiwan and Hungary. 2014 (kézirat). 
10. Granovetter, M.S. (1973): The Strength of Weak Ties. American Journal of Sociology, Volume 78, Issue 6. p. 1360-1380.

11. Granovetter, M.S. (1974): Getting a Job. Study of Contacts and Careers. Cambridge: Harvard University Press.

12. Gyarmati A. (2009): Hogyan verjünk hidat az idősekhez? Az ötven év fölöttiek kommunikációs és kapcsolathálózatának néhány jellemzője. Információs Társadalom, 9. évf. 4. sz. www.epa.oszk.hu/01900/01963/.../infotars_2009_09_04_055-069.pdf

13. Huszti É. (2012): Társas kapcsolatok. Családi, rokoni, baráti kapcsolatok Nyíregyháza lakói körében 2008-2010. In: Fábián G.. Patyán L., Huszti É. (szerk): Életminőség Nyíregyházán 2008-2010. START Nonprofit Kft. Nyíregyháza. pp. 155-176.

14. Huszti É., Dávid B., Vajda K. (2012): Strong tie, weak tie and inbetweens: a linear measure of tie strength based on network diary datasets. Procedia - Social and Behavioral Sciences, 79, 38-61.

15. Johnsen, E. C. (1998): Structures and Processes of Solidarity: An Initial Formalization. In: Doreian, P.-Fararo, T. (eds.): The Problem of Solidarity. Amsterdam, Gordon and Breach Publishers.

16. Kolosi T., Tóth I.Gy. (szerk.): Újratervezés. Életutak és alkalmazkodás a rendszerváltás évtizedeiben. Kutatási jelentés a „Háztartások életút vizsgálata” (HÉV) alapján. 2008. http://www.tarki.hu/hev/hev1/ujratervezes-eletutak-es-alkalmazkodas-a-rendszervaltas-evtizedeiben

17. Marsden, P.V., Campbell, K.E. (1984): Measuring Tie Strenght. Social Forces, 63. p. 482-501.

18. Omnibusz, $2011 \mathrm{http}: / / w w w . a c a d e m i a . e d u / 1428370 /$ TARKI _ Omnibusz_-_Bar_egyre_tobb_a_baratunk_minden_otodik_felnottnek_nincs baratja

19. Riesman, D. (1983): A magányos tömeg. Közgazdasági és Jogi Könyvkiadó, Budapest.

20. Simmel, G. (1973): Válogatott társadalomelméleti tanulmányok. Gondolat Kiadó, Budapest.

21. Szabó L., (2005) A társadalmi támaszt nyújtó személyes kapcsolatháló és a szubjektív életminőség összefüggései az egészséges és mozgáskorlátozott személyek körében. PhD értekezés. http://phd.lib.unicorvinus.hu/95/

22. Takács P., Fábián G. (2012): Egy lokális életminőség index kialakításának lépései. In: Fábián G., Patyán L., Huszti É. (szerk): Életminőség Nyíregyházán 2008-2010. START Nonprofit Kft. Nyíregyháza. pp. 49-68.

23. Utasi Á. szerk. (2006): A szubjektív életminőség forrásai. Biztonság és kapcsolatok. MTA Politikai Tudományok Intézete, Budapest.

24. Utasi Á. (2002): A bizalom hálója. Budapest, Új Mandátum Könyvkiadó. 
25. Utasi Á. (2013): Kötelékben. Szolidaritás-hálók és közélet. Belvedere, Szeged, 2013.

26. Veblen, T.M. (1975): A dologtalan osztály elmélete. Közgazdasági és Jogi Könyvkiadó, Budapest.

Huszti Éva: adjunktus

Debreceni Egyetem Egészségügyi Kar, 4400 Nyíregyháza, Sóstói u. 2-4. 